\title{
Pengaruh Pengetahuan dan Sikap Orang Tua terhadap Motivasi untuk Melengkapi Imunisasi Lanjutan
}

\author{
${ }^{1}$ Z. Rahman*, ${ }^{2}$ Z.Munir, ${ }^{3}$ W.N. Siam \\ ${ }^{1,2,3}$ Program Studi Ilmu Keperawatan, Fakultas Kesehatan, Universitas Nurul Jadid \\ *Email Korespondensi: zaifkhanbro@gmail.com
}

Kata kunci :

Analisis Jalur; Simple

Random Sampling;

Sweeping;

Keywords :

Path Analysis;

Simple Random

Sampling;

Sweeping;

Info Artikel:

Tanggal dikirim:

5 Agustus 2019

Tanggal direvisi:

28 September 2019

Tanggal diterima :

8 Oktober 2019

DOI Artikel:

10.33862/citradelima. v3i2.66

Halaman: 101 - 105

\begin{abstract}
Abstrak
Banyak faktor yang mempengaruhi rendahnya angka bayi dan balita yang berstatus imunisasi lengkap, antara lain sikap dan pengetahuan orang tua. Melalui penelitian ini diharapkan karakteristik orang tua dan karakteristik anak dapat teridentifikasi, selain itu pengaruh pengetahuan dan sikap orang tua terhadap motivasi untuk melengkapi imunisasi lanjutan pada anak usia 18-24 bulan di Kecamatan Pujer juga dapat diketahui. Metode yang digunakan adalah analisis jalur dengan rancangan penelitian cross sectional. Populasi penelitian ini adalah orang tua yang memiliki anak baduta. Sampel yang digunakan sebanyak 81 orang dengan teknik pengambilan sampel menggunakan simple random sampling. Hasil penelitian menunjukkan bahwa, pengetahuan dan sikap orang tua secara langsung berpengaruh signifikan terhadap motivasi, pengetahuan orang tua secara langsung tidak berpengaruh signifikan terhadap kelengkapan imunisasi lanjutan anak baduta, namun sikap dan motivasi orang tua berpengaruh signifikan. Berdasarkan hasil penelitian ini, petugas kesehatan diharapkan bisa lebih aktif memberikan sosialisasi dan konseling serta mempunyai jadwal sweeping bagi sasaran-sasaran yang belum lengkap status imunisasinya
\end{abstract}

\section{The Effect of Parent's Knowledge and Attitude Towards Motivation to Complete Advanced Immunization}

\begin{abstract}
Many factors influence the low number of infants and toddlers who are fully immunized, including attitudes and knowledge of parents. Through this research, it is expected that parents' characteristics and children's characteristics can be identified, in addition to the influence of knowledge and attitudes of parents against motivation to complete continued immunization in children aged 18-24 months in Pujer District can also be known. The method used is path analysis with cross-sectional study design. The population of this study is parents who have children under five. The sample used was 81 people with the sampling technique using simple random sampling. The results showed that knowledge and attitudes of parents directly have a significant effect on motivation, parents 'knowledge directly does not have a significant effect on the completeness of continued immunization of children under five, but parents' attitudes and motivations have a significant effect. Based on the results of this study, health workers are expected to be more active in providing outreach and counseling and have sweeping schedules for targets who have not yet completed their immunization status.
\end{abstract}

\section{PENDAHULUAN}

Imunisasi adalah suatu upaya untuk menimbulkan atau meningkatkan kekebalan seseorang secara aktif terhadap suatu penyakit sehingga bila suatu saat terpajan dengan penyakit tersebut tidak akan sakit atau hanya mengalami sakit ringan. United Nations Children's Fund (UNICEF) menyatakan pada tahun 2005 hampir seperempat dari 130 juta bayi yang lahir tiap tahun tidak diimunisasi agar terhindar dari penyakit anak yang umum. Vaksin telah menyelamatkan jutaan jiwa anak-anak dalam tiga dekade terakhir, namun masih ada jutaan anak lainnya yang tidak terlindungi

http://jurnalilmiah.stikescitradelima.ac.id/index.php/JI Vol.3,No.2, Januari 2020 
dengan imunisasi. Survei yang dilakukan WHO menunjukkan bahwa di beberapa daerah angka imunitas kurang dari 56\%. Tiga tahun sebelumnya angka imunitas mencapai $70 \%$. Lalu pada tahun 2017 terdapat 19,9 juta bayi tidak mendapatkan imunisasi lengkap, yang mana setengahnya merupakan bayi yang tinggal di lima negara, yaitu Ethiopia, India, Nigeria, Pakistan, dan Indonesia.

Berdasarkan data Dinas Kesehatan Provinsi Jawa Timur, jumlah anak belum diimunisasi dan belum lengkap imunisasi dasar bayi tahun 2018 di Jawa Timur adalah sebanyak 26.307 bayi. Persentase anak belum diimunisasi dan belum lengkap imunisasi lanjutan baduta tahun 2018 di Jawa Timur adalah 32,6\% dengan jumlah sebanyak 197.077 baduta. Menurut data dari Dinas Kesehatan Kabupaten Bondowoso bahwa pada tahun 2018 terdapat 332 bayi belum diimunisasi dan belum lengkap imunisasi dasar bayi. Persentase terbesar terdapat di Puskesmas Taman Krocok, Prajekan dan Tegalampel. Selanjutnya, jumlah anak belum diimunisasi dan belum lengkap imunisasi lanjutan baduta tahun 2018 adalah sebanyak 6.895 baduta. Persentase terbesar berada di Puskesmas Botolinggo, Wonosari dan Puskesmas Pujer. Hal ini menunjukkan bahwa masih banyaknya sasaran bayi dan baduta yang masih belum lengkap status imunisasinya bahkan masih tinggi cakupan yang belum di imunisasi.

Beberapa alasan bayi tidak mendapatkan imunisasi lengkap dinyatakan oleh menteri kesehatan Indonesia yaitu karena alasan informasi, motivasi dan situasi. Alasan informasi berupa kurangnya pengetahuan ibu tentang kebutuhan, kelengkapan dan jadwal imunisasi, ketakutan akan imunisasi dan adanya persepsi salah yang beredar di masyarakat tentang imunisasi. Penjelasan tersebut menunjukkan banyak faktor yang mempengaruhi alasan bayi tidak mendapatkan imunisasi lengkap.

Hal tersebut sesuai dengan kesimpulan dalam penelitian yang dilakukan oleh Yaqub dkk. Penelitian tersebut menyatakan bahwa perhatian terhadap keamanan imunisasi menjadi penyebab keraguan orang tua. Kekhawatiran ini disebabkan karena tidak adanya wadah bagi mereka untuk melaporkan kejadian pasca imunisasi. Penelitian lain oleh Kennedy dkk menyatakan bahwa pelayan kesehatan memiliki peranan penting dalam membangun kepercayaan tentang keamanan dan manfaat vaksin.
Berdasarkan fenomena diatas, dapat disimpulkan bahwa dalam melengkapi imunisasi lanjutan pada anak usia 18-24 bulan berkaitan erat dengan pengetahuan, sikap dan motivasi orang tua. Pada penelitian ini, peneliti menganalisis pengaruh pengetahuan dan sikap orang tua tentang imunisasi terhadap motivasi untuk melengkapi imunisasi lanjutan pada anak usia 18-24 bulan di Kecamatan Pujer.

\section{METODE}

Penelitian ini termasuk penelitian kuantitatif dengan rancangan penelitian cross sectional. Populasi pada penelitian ini adalah orang tua yang memiliki anak usia 18-24 bulan di Kecamatan Pujer, yaitu sebanyak 471 orang, dan sampel yang digunakan adalah 81 orang tua dengan anak usia 18-24 bulan. Pengambilan sampel dilakukan dengan teknik Simple Random Sampling. Metode analisis data menggunakan analisis jalur. Analisis jalur berbentuk diagram yang memiliki persamaan yang kompleks sehingga memiliki lebih dari satu persamaan. Oleh karena itu, diperlukan penyebutan variabel dalam analisis jalur. Menurut Li penyebutan variabel dalam model analisis jalur adalah variabel eksogen, yaitu variabel yang tidak dipengaruhi variabel lain dalam model sehingga selalu menjadi variabel independen.Pada penelitian ini yang termasuk dalam variabel eksogen adalah pengetahuan dan sikap orang tua.

Selanjutnya adalah variabel endogen yaitu variabel yang nilainya ditentukan atau dipengaruhi oleh variabel lain dalam model. Variabel endogen dapat berupa variabel dependen dan variabel independen. Pada penelitian ini yang termasuk dalam variabel endogen adalah motivasi orang tua dan kelengkapan imunisasi lanjutan.

\section{HASIL DAN PEMBAHASAN}

Sebanyak 81 orang tua berpatisipasi dalam penelitian ini dan menghasilkan karakteristik sebagai berikut.

Tabel 1. Distribusi Responden Berdasarkan Umur, Status Hubungan dengan Anak, Pendidikan Terakhir, dan Pendapatan orang tua

http://jurnalilmiah.stikescitradelima.ac.id/index.php/JI Vol.3,No.2, Januari 2020 


\begin{tabular}{lcc}
\hline $\begin{array}{c}\text { Karakteristik } \\
\text { Responden }\end{array}$ & Frekuensi & Persentase \\
\hline \multicolumn{2}{c}{ Umur } & \\
\hline 25 tahun & 16 & $19,8 \%$ \\
\hline $31-35$ tahun & 42 & $51,9 \%$ \\
\hline$>35$ tahun & 15 & $18,5 \%$ \\
\hline
\end{tabular}

\begin{tabular}{lcc}
\hline $21-22$ Bulan & 19 & $23,5 \%$ \\
\hline $23-24$ Bulan & 15 & $18,5 \%$ \\
\hline & Jenis Kelamin \\
\hline Perempuan & 45 & $55,6 \%$ \\
\hline Laki-laki & 36 & $44,4 \%$
\end{tabular}

Berdasarkan Tabel 2 sebagian besar anak

Status hubungan responden dengan anak

\begin{tabular}{lcc}
\hline Bapak & 7 & $8,6 \%$ \\
\hline Ibu & 74 & $91,4 \%$ \\
\hline \multicolumn{3}{c}{ Pendidikan Terakhir } \\
\hline SD & 39 & $41,8 \%$ \\
\hline SMP & 19 & $23,5 \%$ \\
\hline SMA & 15 & $18,5 \%$ \\
\hline Perguruan Tinggi & 8 & $9,9 \%$ \\
\hline \multicolumn{3}{r}{$\begin{array}{l}\text { Pendapatan } \\
\text { < Rp1.000.000 }\end{array}$} \\
\hline $\begin{array}{l}\text { Rp1.000.000- } \\
\text { Rp1.500.000 }\end{array}$ & 12 & $14,8 \%$ \\
\hline$>$ Rp.1.500.00 0 & 49 & $60,5 \%$ \\
Rp2.000.000 & 14 & $17,3 \%$ \\
\hline$>2.000 .000$ & & $7,4 \%$ \\
\hline
\end{tabular}

Tabel 1 menjelaskan karakteristik orang tua umumnya berumur 25-30. Mayoritas merupakan ibu dari anak baduta dengan persentase sebesar $91,4 \%$. Pada penelitian ini, terdapat 39 orang atau orang tua yang pendidikan terakhirnya adalah sekolah dasar. Mayoritas orang tua berpendapatan Rp.1.000.000 Rp.1.500.000 per bulan dengan persentase sebesar $60,5 \%$.

Tabel 2. Distribusi Responden Berdasarkan Umur, dan Jenis Kelamin Anak

\begin{tabular}{lcc}
\hline $\begin{array}{c}\text { Karakteristik } \\
\text { Responden }\end{array}$ & Frekuensi & Persentase \\
\hline \multicolumn{3}{c}{ Umur } \\
\hline 18 Bulan & 14 & $17,3 \%$ \\
\hline $19-20$ Bulan & 33 & $40,7 \%$
\end{tabular}

Hasil penelitian didapatkan pengetahuan secara langsung berpengaruh signifikan terhadap motivasi orang tua dengan koefisien beta 0,3 . Pengetahuan dapat diartikan sebagai kesiapan seseorang yang mana sudah mengetahui dan pernah mengalami kejadian tersebut sehingga memberikan pengaruh dinamik atau terarah terhadap respon individu pada suatu obyek dan situasi yang berpengaruh dengannya. Pengetahuan

http:/jurnalilmiah.stikescitradelima.ac.id/index.php/JI Vol.3,No.2, Januari 2020 
dapat mempengaruhi perubahan status kesehatan keluarga (Mubarak, 2011).

Menurut peneliti hal ini dapat dijelaskan bahwa peningkatan pengetahuan orang tua mengenai imunisasi dapat berdampak terhadap meningkatnya motivasi orang tua untuk melengkapi status imunisasi lanjutan anaknya. Meskipun demikian, pengetahuan tidak berpengaruh signifikan secara langsung terhadap kelengkapan imunisasi. Seperti yang disampaikan oleh Mubarak, pengetahuan yang dicakup di dalam domain kognitif mempunyai enam tingkat yaitu, tahu paham, aplikasi, analisa, sintesis, dan evaluasi. Berdasarkan hal tersebut, menurut peneliti pada tahap ini tingkat pengetahuan orang tua masih dalam tahap pertama yaitu tahap tahu, artinya orang tua hanya mengingat suatu materi tentang imunisasi yang telah dipelajari sebelumnya, tanpa memahami lebih dalam mengenai efek atau akibat yang ditimbulkan apabila tidak melengkapi status imunisasi lanjutan. Tahap tahu merupakan tingkat pengetahuan yang paling rendah. Hasil penelitian didapatkan sikap secara langsung berpengaruh signifikan terhadap motivasi orang tua dengan koefisien beta 0,419 , dan juga terhadap kelengkapan imunisasi dengan koefisien beta 0,272.

Hasil penelitian yang dilakukan oleh Hindun $S$ (2009) menyatakan bahwa ibu yang memiliki sikap positif menunjukkan cakupan imunisasi dasar lengkap yang lebih tinggi pada anaknya dibandingkan ibu yang memiliki sikap negatif. Menurut peneliti hal ini dapat dijelaskan bahwa semakin positif sikap orang tua terhadap program imunisasi, maka motivasi orang tua untuk melengkapi imunisasi lanjutan anak badutanya juga akan meningkat. Sikap manusia terbentuk melalui proses sosial yang terjadi selama hidupnya, dimana individu mendapatkan informasi dan pengalaman. Proses tersebut dapat berlangsung di dalam lingkungan keluarga, sekolah maupun masyarakat. Tidak ada responden yang bersikap menolak imunisasi, sehingga berdasarkan hal tersebut dapat diperkirakan bahwa responden memiliki lingkungan yang bersikap positif pula terhadap imunisasi.

Secara langsung pengetahuan tidak berpengaruh signifikan terhadap kelengkapan imunisasi dengan koefisien beta 0,001 . Tetapi, keadaan akan terbalik bila pengetahuan melewati motivasi maka akan ada pengaruh yang signifikan pada kelengkapan imunisasi dengan koefisien beta 0,2073. Artinya, pengetahuan orang tua akan mampu melengkapi status imunisasi anak bila adanya motivasi dari lingkungan sekitar, baik dari keluarga maupun tenaga medis.

Menurut peneliti terdapat orang tua yang memiliki motivasi cukup tinggi untuk melengkapi imunisasi anaknya walaupun bepengetahuan kurang, peningkatan motivasi ini kemungkinan dapat disebabkan oleh faktor yang lain, seperti dukungan keluarga. Sikap dan perilaku yang baik akan terwujud karena adanya stimulus internal yang adekuat. Stimulus tersebut adalah pengetahuan dan tanggapan ibu terhadap masalah yang dihadapi (Notoatmodjo, 2003).

Sikap terbentuk oleh komponen kognitif, komponen emosiona dan komponen perilaku (Donsu, 2017). Menurut peneliti dengan mempunyai sikap yang baik maka orang tua mempunyai kesiapan atau kesediaan untuk bertindak atau mengambil keputusan dalam pemeliharaan kesehatan anak, dalam hal ini untuk melengkapi status kelengkapan imunisasi. Sikap yang cukup dan kurang menunjukkan kurangnya kemauan dalam bertindak untuk melengkapi status imunisasi anaknya.

Hasil penelitian menunjukkan bahwa motivasi orang tua berpengaruh signifikan terhadap kelengkapan imunisasi anak dengan koefisien beta 0,691.

Sesuai dengan teori yang disampaikan oleh Sudrajat (2019) bahwa motivasi adalah kekuatan (energi) seseorang yang dapat menimbulkan tingkat konsistensi dan antusiasmenya dalam melakukan sesuatu kegiatan, baik bersumber dari dalam individu itu sendiri (motivasi intrinsik) maupun dari luar individu (ekstrinsik).

Menurut peneliti hal ini dapat dijelaskan bahwa apabila seseorang memiliki kekuatan atau energi yang cukup besar untuk melakukan suatu hal, maka mereka akan melakukannya dengan antusias dan konsisten. Suatu hal atau kegiatan yang dimaksud adalah membawa anak ke fasilitas kesehatan untuk mendapatkan imunisasi. Orang tua dengan motivasi yang besar, akan secara konsisten memberikan imunisasi pada anak hingga anak mendapatkan imunisasi yang lengkap.

\section{SIMPULAN}

Berdasarkan penelitian analisis pengaruh pengetahuan dan sikap terhadap motivasi orang tua terhadap kelengkapan imunisasi anak usia 18-24 bulan

http://jurnalilmiah.stikescitradelima.ac.id/index.php/JI Vol.3,No.2, Januari 2020 
di Kecamatan Pujer, diketahui bahwa Pengetahuan dan sikap orang tua berpengaruh signifikan terhadap motivasi dengan besaran nilai pengaruh secara berurutan 0,3 (cukup) dan 0,419 (cukup).

Pengetahuan orang tua tidak berpengaruh signifikan terhadap kelengkapan imunisasi anak dengan besaran nilai pengaruh 0,001 (kurang). Sedangkan sikap dan motivasi orang tua berpengaruh signifikan dengan besaran nilai pengaruh secara berurutan 0,272 (cukup) dan 0,691 (kuat).

Pengetahuan dan sikap berpengaruh terhadap kelengkapan imunisasi anak dalam motivasi orang tua dengan besaran nilai pengaruh secara berurutan 0,2083 (kurang) dan 0,5615 (baik).

\section{DAFTAR PUSTAKA}

A. Kennedy, K. LaVail, G. Nowak, M. Basket, \& S. Landry, (n.d.). Confidence About Vaccine in The United States : Understanding Parents' Perceptions. Strategies For The Decade of Vaccines

Dinas Kesehatan Bondowoso, 2019, Profil Dinas Kesehatan Bondowoso Tahun 2018. Bondowoso, Dinas Kesehatan Bondowoso

J. Donsu, 2017, Psikologi Keperawatan. Yogyakarta : Pustaka Baru Press.

M. Olpinski ,2012, Anti-Vaccination Movement and Parental Refusals of Immunization of Children in USA. Pediatra Polska, 381-385.

N. Hidayah, H. M. Sihotang, W. Lestari, 2017, Faktor yang Berhubungan dengan Pemberian Imunisasi Dasar Lengkap Pada Bayi Tahun 2017.

O. Yaqub, S. Castle-clarke, N. Sevdalis, and J. Chataway, "Social Science \& Medicine Attitudes to vaccination: A critical review," Soc. Sci. Med., vol. 112, pp. 1-11, 2014.

S. Hindun, 2009, Hubungan antara pengetahuan dan sikap ibu dengan status kelengkapan imunisasi dasar pada balita di wilayah kerja puskesmas Swakelola Gandus palembang. Palembang : Politekhnik kesehatan palembang.
S. Notoadmojo, 2003, Ilmu Kesehatan Masyarakat Prinsip-Prinsip dasar. Jakarta : Rhineka Cipta.

W. Mubarak, 2011, Promosi kesehatan. Yogyakarta: Graha ilmu.

Z. Munir, 2017, Analisis pengaruh Pendidikan, Pendapatan dan Pekerjaan terhadap Motivasi Orangtua dalam Kualitas Perawatan Anak dengan HIV/AIDS. Universitas Muhammadiyah Jakarta.

Z. Munir \& F. Romadhoni, 2019, Pengaruh Pendidikan Dan Pekerjaan Orangtua Dengan Tingkat Kepatuhan Arv Pada Anak HIV / AIDS. Jurnal Ilmiah STIKES Citra Delima Bangka Belitung, $2,131-135$ 